\title{
Characterisation of host rocks and hydrothermal alteration of the Qussuk gold occurrence, southern West Greenland
}

\author{
Denis Martin Schlatter and Rasmus Christensen
}

Gold exploration in the Godthåbsfjord region has been carried out since the early 1990s, and the region is now recognised as a gold province. Several prospects have been drilled and Storø is the most advanced project in the Færingehavn terrane. The gold occurrence at Storø is $2635 \mathrm{Ma}$ old according to ${ }^{207} \mathrm{~Pb} /{ }^{206} \mathrm{~Pb}$ age determinations of metamorphic zircons associated with auriferous arsenopyrite (Nutman et al. 2007). Qussuk is located in the Akia terrane (Fig. 1), separated from the Færingehavn terrane in the south by the SW-NE-trending Ivinnguit fault. The Ivinnguit and Ataneq faults are spatially associated with several hydrothermal gold occurrences. From north to south these are: Isua, Storø, Bjørneøen, Sadelø, Store Malene and Qilanngaarsuit (Fig. 1; Appel et al. 2005; Kolb et al. 2009). The Qussuk prospect $20-25 \mathrm{~km}$ north of the Ataneq fault is $20 \mathrm{~km}$ long, 2-3 km wide, and divided from north to south into the 'Swan N', 'Swan' and 'Plateau' areas (Fig. 1).

In this study, geology, petrography and immobile element geochemistry are used to define a vector to the ore, and we will demonstrate that the Qussuk gold mineralisation shows many characteristics of orogenic gold deposits. This paper is directed towards helping gold exploration to be more efficient in the Qussuk area, in the larger Godthåbsfjord region and elsewhere in the Achaean greenstone belts of southern West Greenland.

\section{Geology of the Qussuk area}

The supracrustal rocks are deformed and metamorphosed to amphibolite grade and comprise amphibolite, ultramafic rocks, aluminous gneiss and tonalite (Garde 1997). Deformation is characterised by upright to overturned isoclinal folds; the rocks trend NNE-SSW and are steeply dipping (Garde 2008). The tonalitic orthogneiss precursor intruded into the volcanic rocks dated at $3071 \pm 1 \mathrm{Ma}$ in the Qussuk area (U-Pb zircon age) whereas tonalitic orthogneiss is 3060-3000 Ma old (Garde et al. 2000). Plagioclase-rich amphibolite units containing both biotite and hornblende are possibly of pyroclastic or volcaniclastic origin as suggested by primary textures such as graded bedding, fragmental textures and fiamme structures (Garde 2007; Garde et al. 2007). These primary volcanic textures and the presence of calc-alkaline and tholeiitic andesites at Qussuk led Garde (2007) to the conclusion that these rocks represent an Archaean island arc complex.

A $120 \mathrm{~m}$ thick sequence of leuco-amphibolite, amphibolite, aluminous gneiss, biotite schist and pegmatite dykes is found in the 'Swan N' area (Fig. 2). At the contact between the aluminous gneiss and the leuco-amphibolite a $23 \mathrm{~m}$ thick zone consists mainly of biotite schist with $5-30 \mathrm{~cm}$ thick quartz veins and quartz rods. This zone is interpreted as a hydrothermal alteration zone (Schlatter \& Christensen 2010). Continuous sampling of 1-2 $\mathrm{m}$ long sections reveals that the gold content averages 1.24 ppm over $23 \mathrm{~m}$ including several 1-2 $\mathrm{m}$ thick layers of biotite schist with gold contents between 3.3 and $8.4 \mathrm{ppm}$ (Schlatter \& Christensen 2010).

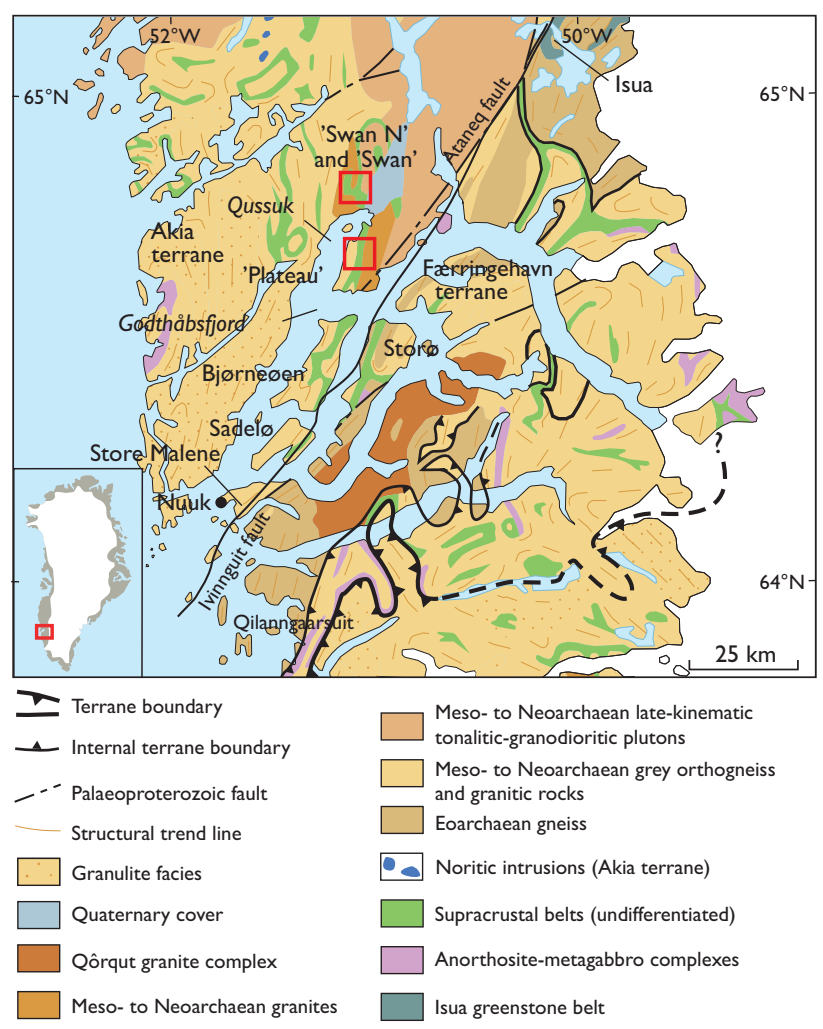

Fig. 1. Geological map of the Godthåbsfjord region showing gold occurrences. The Qussuk prospect is divided into the 'Swan N', 'Swan' and 'Plateau' areas. The red boxes show the Qussuk prospect. 


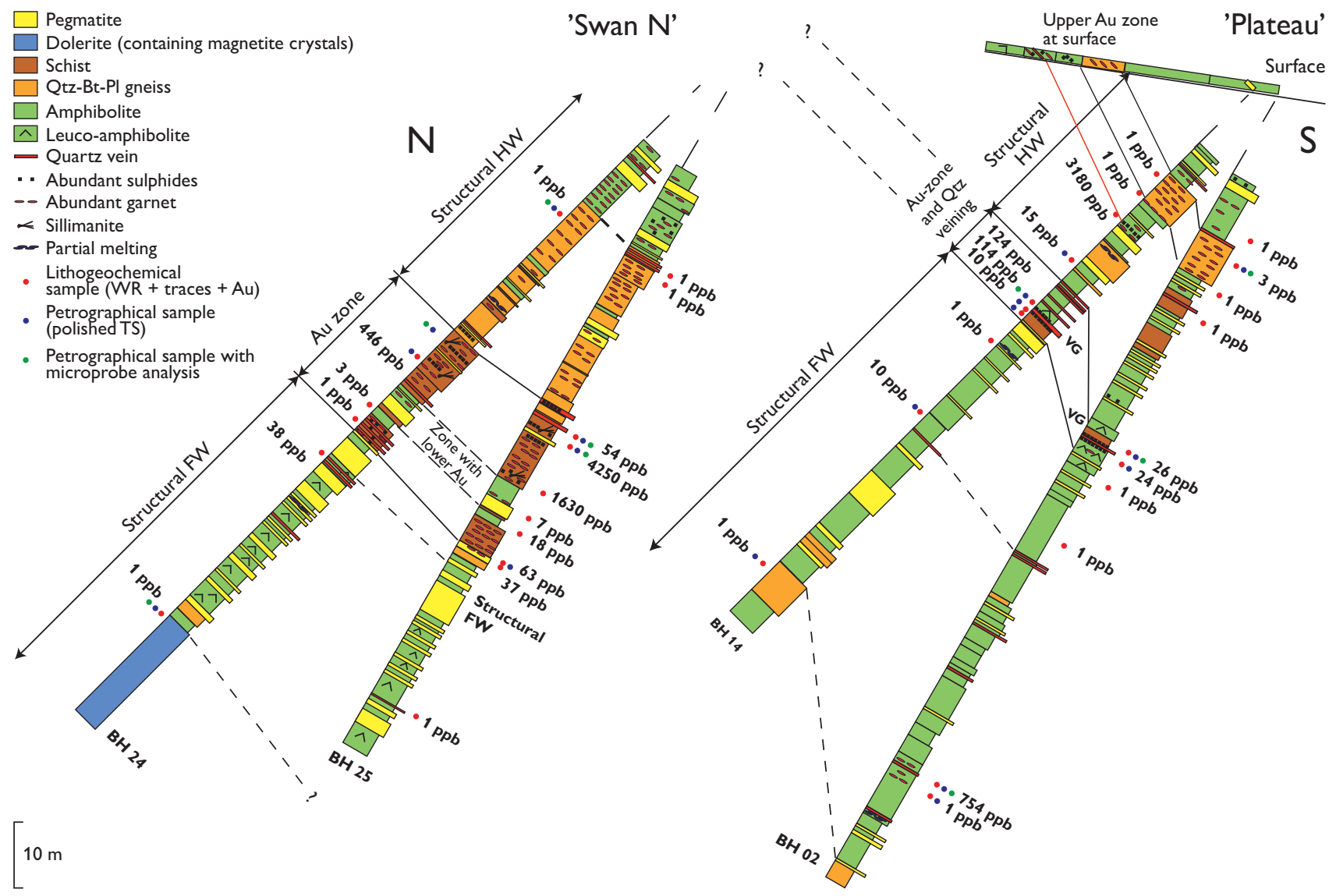

Fig. 2. Borehole logs of BH 24 and BH 25 from 'Swan N' and of BH 02 and 14 from 'Plateau'. The geology is defined from the two bore holes and from outcrops. The alteration zones are narrower in the Plateau area (a few metres) and wider in the 'Swan N' area (tens of metres), possibly because the areas represent wider and narrower shear zones and in turn focus alteration fluids differently. Only the gold contents in the lithogeochemical samples are shown.

A $100 \mathrm{~m}$ thick sequence with amphibolite, aluminous gneiss, biotite schist, leuco-amphibolite and pegmatite dykes occurs in the 'Plateau' area (Fig. 2). Several up to $0.5 \mathrm{~m}$ thick quartz veins occur at or close to the contact of amphibolite and leuco-amphibolite. One of these contains visible gold and is flanked by a $0.5 \mathrm{~m}$ thick inner zone of semi-massive to massive pyrrhotite and an outer zone of biotite-quartz alteration products. Analyses of the quartz veins and the inner alteration zone yielded up to $19 \mathrm{ppm}$ gold over $0.6 \mathrm{~m}$ (Schlatter \& Christensen 2010). The local rock sequences at 'Plateau' and 'Swan N' are different from each other and no straightforward detailed correlation can be made between the two areas, although they both belong to the same Qussuk-Bjørneøen metavolcanic belt (Garde 2007; Garde et al. 2007). The gold-enriched zones in both areas occur close to lithological contacts (Fig. 2) and are structurally controlled by local shear zones and quartz veins. In the 'Swan' area no intersection with gold concentrations above $1 \mathrm{ppm}$ was encountered.

\section{Methods}

Analysed drill core sections were $20-25 \mathrm{~cm}$ long and a quarter of the core was used. All samples were crushed in Nuuk and analysed at the Actlabs laboratory in Ontario, Canada. Gold was analysed by instrumental neutron activation. A total of 46 drill core samples and eight surface samples were used for geochemical and petrographical investigations. Ten thin sections ( 242 spots) were analysed by a JEOL JXA- 8200 superprobe at the Department of Geography and Geology, University of Copenhagen to determine the chemistry of the main rock phases.

\section{Hydrothermal alteration and lithogeochemical results}

The gold mineralisation comprises quartz veins with visible gold and massive or disseminated pyrrhotite. Hydrothermal alteration zones at 'Swan N' and 'Plateau' comprise an inner zone of pyrrhotite, chalcopyrite and gold-quartz veins and 

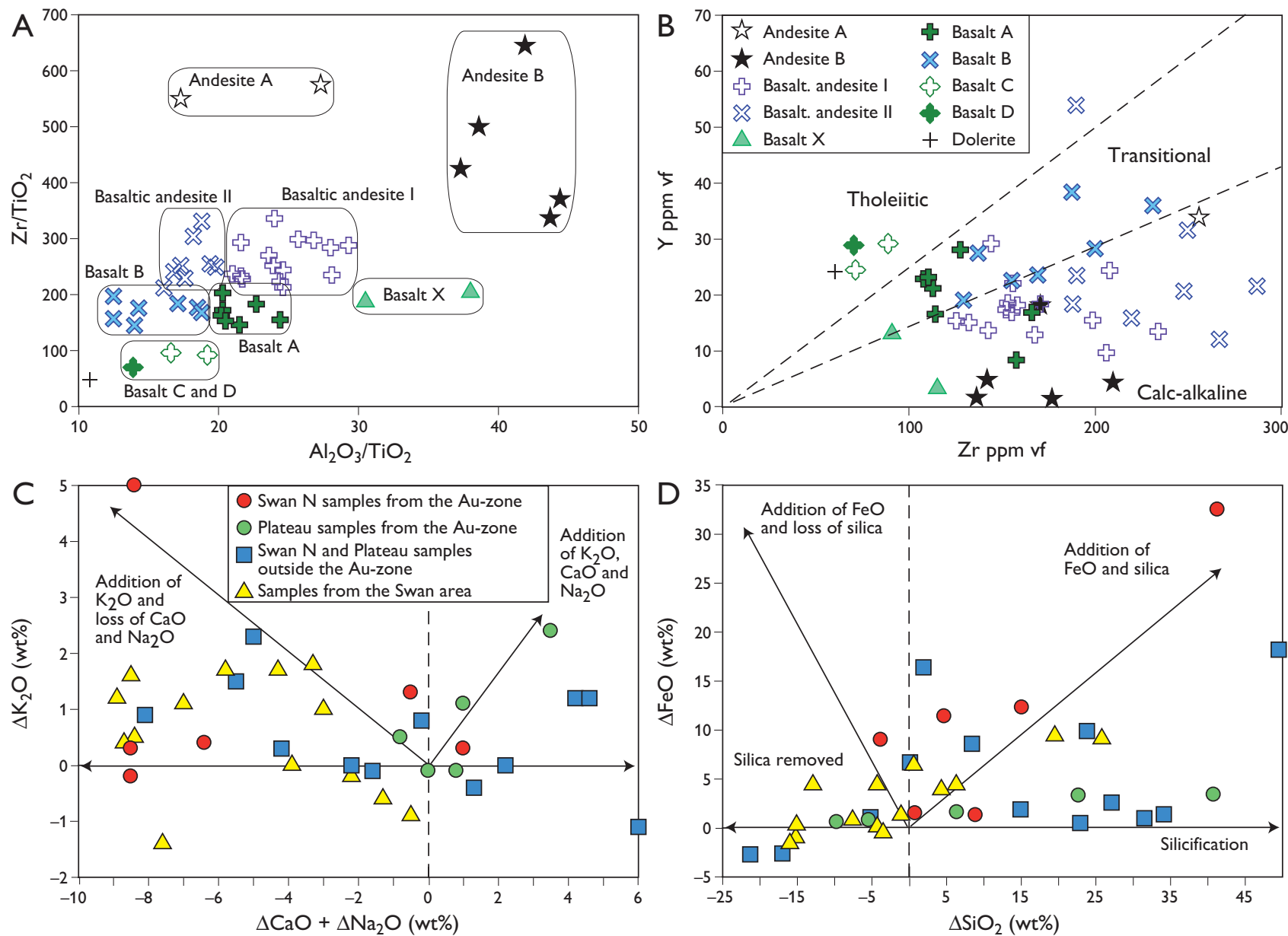

Fig. 3. A: $\mathrm{Ti}, \mathrm{Al}$, and $\mathrm{Zr}$ are commonly considered to be immobile during hydrothermal processes and so their ratios show as primary lithological variations that have not been affected by hydrothermal alteration. The chemical groups form fairly tight clusters in a diagram based on $\mathrm{Al}_{2} \mathrm{O}_{3} / \mathrm{TiO}_{2}$ versus $\mathrm{Zr} / \mathrm{TiO}{ }_{2}$ and show eight main chemical groups ranging from andesite to basalt (division from Barrett \& MacLean 1994). B: A diagram based on $\mathrm{Zr}$ and $\mathrm{Y}$ shows that most of the Qussuk samples have calc-alkaline and transitional magmatic affinity; only a few samples plot in the tholeiitic field (division from Barrett \& MacLean 1994). C: $\Delta \mathrm{K}_{2} \mathrm{O}$ versus $\Delta \mathrm{CaO}+\Delta \mathrm{Na}_{2} \mathrm{O}$ for rocks of the 'Swan N', 'Swan' and 'Plateau' areas. D: $\Delta \mathrm{FeO}$ versus $\Delta \mathrm{SiO}_{2}$ for rocks of the Swan $\mathrm{N}$, Swan and Plateau areas. $(\mathbf{v f}=$ volatile-free basis, data were normalised after loss on ignition (LOI); results of mass change calculations are reported in wt $\%$ change $(\Delta)$ relative to the precursor rock).

an outer zone of biotite, muscovite, quartz, and sulphides (Fig. 2). Garnet and sillimanite also occur in the outer zone (Fig. 2), but it is unclear if these are primary metamorphic or hydrothermal alteration minerals. Chlorite replacing biotite and actinolite replacing pyroxene are regarded as retrograde metamorphic minerals.

Application of immobile element methods (Barrett \& MacLean 1994) on 50 whole-rock analyses shows that the rocks from 'Plateau', 'Swan N' and 'Swan' can be classified into ten different chemical groups ranging from andesite to basalt (Fig. 3A). The rocks are mainly metabasalts with transitional to calc-alkaline affinity (Fig. 3A, B). A few are tholeiitic (Fig. 3B). The rocks from the gold zones in the 'Swan $\mathrm{N}$ ' and 'Plateau' areas are mainly basaltic andesite I of calcalkaline affinity.
Hydrothermal alteration can cause mass gain or loss, which in turn results in dilution or residual concentration of the immobile elements. However, these effects do not change the initial ratio between two immobile elements for a given chemical rock type. Mass changes were calculated using the single precursor approach (MacLean \& Barrett 1993). The rocks from the 'Swan N' and 'Plateau' areas show gains or losses in $\mathrm{Na}_{2} \mathrm{O}$ and $\mathrm{CaO}$ and gains and small losses in $\mathrm{K}_{2} \mathrm{O}$ (Fig. $3 \mathrm{C}$ ). The rocks from the 'Swan' area show losses in $\mathrm{CaO}$ and $\mathrm{Na}_{2} \mathrm{O}$ and gains and small losses of $\mathrm{K}_{2} \mathrm{O}$ (Fig 3C). Most of the samples from the 'Swan N' and 'Plateau' areas have gained $\mathrm{FeO}$ and $\mathrm{SiO}_{2}$, and a few samples have lost $\mathrm{SiO}_{2}$ and show minor losses in $\mathrm{FeO}$ (Fig. 3D) Samples from the 'Swan' area show losses and gains of $\mathrm{SiO}_{2}$ and gains or small losses of $\mathrm{FeO}$ (Fig. 3D). 


\section{Discussion and conclusions}

Garde (2007) showed that the rocks of the Qussuk area were formed in a volcanic-arc setting and that they were altered during a synvolcanic and epithermal hydrothermal alteration stage, and suggested that gold was introduced during this epithermal event. The presence of plagioclase in rocks from the gold zone, however, suggests that these rocks are neither strongly altered nor extremely affected by acid leaching, because such alteration would cause breakdown of plagioclase due to leaching of $\mathrm{Na}_{2} \mathrm{O}$ and $\mathrm{CaO}$. Results from mass change calculations show that several samples from the gold zones have gained $\mathrm{Na}_{2} \mathrm{O}$ and $\mathrm{CaO}$ or lost only a small part of these mobile elements (Fig. 3C).

The gold occurrences from the 'Swan N' and the 'Plateau' areas are enveloped by biotite schist, which represents enveloping and symmetric hydrothermal alteration halos around the gold mineralisation. Gains of $\mathrm{K}_{2} \mathrm{O}$ (Fig. 3C) suggest that biotite formed as a result of hydrothermal alteration which is well known in orogenic gold systems (Eilu \& Groves 2001; Groves et al. 2003). The occurrence of gold-rich quartz veins and biotite-quartz-sulphide-rich hydrothermal alteration together with mass change calculations (Fig. 3C, D) suggest that the hydrothermal fluids were enriched in $\mathrm{K}_{2} \mathrm{O}, \mathrm{SiO}_{2}, \mathrm{FeO}$ and $\mathrm{Au}$. The quartz veins with visible gold and the inner pyrrhotite alteration zone cross-cut the main foliation, indicating that the veining occurred later than the formation of the foliation and shows that the gold mineralisation took place during later stages of deformation and metamorphism. Metamorphic minerals of slightly lower metamorphic grade replacing minerals of higher metamorphic grade indicate that hydrothermal gold mineralisation occurred during retrograde upper greenschist to lower amphibolite facies metamorphism.

The present study shows that gold in the Qussuk area is controlled by post-peak, metamorphic, hydrothermal quartz veins and alteration zones akin to orogenic gold systems. However, it remains unclear whether the gold was remobilised from an earlier, possibly syngenetic enrichment or introduced from an external source.

In order to find more gold-mineralised systems in the Qussuk area, rocks of basaltic andesite I should be identified. This rock type is a potential target if the layer is enveloped by proximal alteration (quartz veins, pyrrhotite, elevated gold) and distal alteration (biotite, muscovite, quartz, sulphides, elevated gold concentration).

\section{Acknowledgements}

NunaMinerals A/S is thanked for financial contribution to the project.

\section{References}

Appel, P.W.U., Coller, D., Vincent, C., Heijlen, W., Moberg, E.D., Polat, A., Raith, J., Schjøth, F., Stendal, H. \& Thomassen, B. 2005: Is there a gold province in the Nuuk region? Report from field work carried out in 2004. Danmarks og Grønlands Geologiske Undersøgelse Rapport 2005/27, 79 pp. + 1 CD-Rom.

Barrett, T.J. \& MacLean, W.H. 1994: Chemostratigraphy and hydrothermal alteration in exploration for VHMS deposits in greenstones and younger volcanic rocks. In: Lentz, D.R. (ed.): Alteration and alteration processes associated with ore-forming systems. St. John's: Geological Association of Canada. Short Course Notes 11, 433-467.

Eilu, P. \& Groves, D.I. 2001: Primary alteration and geochemical dispersion haloes of Archaean orogenic gold deposits in the Yilgarn Craton: the pre-weathering scenario. Geochemistry: Exploration, Environment, Analysis 1, 183-200.

Garde, A.A. 1997: Accretion and evolution of an Archaean high-grade grey gneiss-amphibolite complex: the Fiskefjord area, southern West Greenland. Geology of Greenland Survey Bulletin 177, 115 pp.

Garde, A.A. 2007: A mid-Archaean island arc complex in the eastern Akia terrane, Godthåbsfjord, southern West Greenland. Journal of the Geological Society (London) 164, 565-579.

Garde, A.A. 2008: Geochemistry of Mesoarchaean andesite rocks with epithermal gold mineralisation at Qussuk and Bjørneøen, southern West Greenland. Mineral resource assessment of the Archaean Craton $66^{\circ}$ to $63^{\circ} 30^{\prime}$ N) SW Greenland, contribution no. 8. Danmarks og Grønlands Geologiske Undersøgelse Rapport 2008/4, 52 pp.

Garde, A.A., Friend, C.R.L., Nutman, A.P. \& Marker, M. 2000: Rapid maturation and stabilisation of middle Archaean continental crust: the Akia terrane, southern West Greenland. Bulletin of the Geological Society of Denmark 47, 1-27.

Garde, A.A., Stendal, H. \& Stensgaard, B.M. 2007: Pre-metamorphic hydrothermal alteration with gold in a mid-Archaean island arc, Godthåbsfjord, West Greenland. Geological Survey of Denmark and Greenland Bulletin 13,37-40.

Groves, D.I., Goldfarb, R.J., Robert, F. \& Hart, C.J.R. 2003: Gold deposits in metamorphic belts: overview of current understanding, outstanding problems, future research, and exploration significance. Economic Geology 98, 1-29.

Kolb, J., Stensgaard, B.M., Schlatter, D.M. \& Dziggel, A. 2009: Controls of hydrothermal quartz vein mineralisation and wall rock alteration between Ameralik and Sermilik, southern West Greenland. Danmarks og Grønlands Geologiske Undersøgelse Rapport 2009/25, 76 pp. + 1 DVD.

MacLean, W.H. \& Barrett T.J. 1993: Lithogeochemical techniques using immobile elements. Journal of Geochemical Exploration 48, 109-133.

Nutman, A.P., Christiansen, O. \& Friend, C.R.L. 2007: 2635 Ma amphibolite facies gold mineralisation near a terrane boundary (suture?) on Storø, Nuuk region, southern West Greenland. Precambrian Research 159, 19-32.

Schlatter, D.M. \& Christensen R. 2010: Geological, petrographical and lithogeochemical investigations on the Qussuk gold mineralisation, southern West Greenland. Danmarks og Grønlands Geologiske Undersøgelse Rapport 2010/10, 53 pp.

\footnotetext{
Authors' addresses

D.M.S., Geological Survey of Denmark and Greenland, Øster Voldgade 10, DK-1350 Copenhagen K, Denmark. E-mail:dms@geus.dk

R.C., NunaMinerals A/S, Postboks 790, DK-3900 Nuuk, Greenland.
} 